\title{
Epistatic gene control on the yield of tomato at medium elevation in the tropical agroecosystem
}

\author{
FAJAR PRAKOSO MAWASID ${ }^{1}$, MUHAMAD SYUKUR ${ }^{2, \bullet}$, TRIKOESOEMANINGTYAS ${ }^{2}$ \\ ${ }^{1}$ Program of Plant Breeding and Biotechnology, Graduate School, Institut Pertanian Bogor. Jl. Raya Dramaga, Kampus IPB Dramaga, Bogor 16680, \\ West Java, Indonesia, email: fajar.mawasid@gmail.com \\ ${ }^{2}$ Departement of Agronomy and Horticulture, Faculty of Agriculture, Institut Pertanian Bogor. Jl. Meranti, Kampus IPB Darmaga, Bogor 16680, \\ West Java, Indonesia. Tel./fax.: +62-251-8629353. `email: muhsyukur@yahoo.com
}

Manuscript received: 29 April 2019. Revision accepted: 18 June 2019

\begin{abstract}
Mawasid FP, Syukur M, Trikoesoemaningtyas. 2019. Epistatic gene control on the yield of tomato at medium elevation in the tropical agroecosystem. Biodiversitas 20: 1880-1886. Cultivation of tomatoes on the middle-low plain generally decreases the quantity and quality of the yield due to high-temperature stress. Increasing the size and weight of lowland tomatoes is needed to enhance national production. Information on the action and genetic model of target characters is needed in the preparation of the assembly program, especially for selection needs. This study aims to obtain genetic information and heritability of tomato yield characters, as a basis for assembling large tomato varieties for the lowlands. The study was conducted using six populations (P1, P2, F1, BCP1, BCP2, and F2) resulting from two different crosses of 99D x Tora (C-I) and 97D x Tora (C-II). The results show that the action of non-additive genes and non-allelic interactions has a large value, with duplicate epistasis being more dominant than complementary epistasis. Duplicate epistasis was found in the character of harvest time, fruit length, fruit diameter, fruit weight in cross I and flowering time, harvest time, fruit length, fruit diameter, and number of fruits in cross II, while complementary epistasis was found in flowering time, fruit weight per plant, number of fruits in cross I, and fruit weight, fruit weight per plant in cross II. Moderate to high heritability was found in the character of fruit length, fruit diameter, fruit weight, and fruit weight per plant. The values are higher in population from the cross I (99D x Tora) for each character, indicating that the cross I has a higher potential for genetic progress than cross II. Selection is recommended when the homozygosity has increased, using the Bulk method or Single Seed Decent. The two methods above can maintain variability in the next generation, so epistasis genes that control target characters are not drastically eliminated.
\end{abstract}

Keywords: Epistasis, heritability, scaling test, tomato, yield component

\section{INTRODUCTION}

Tomato is the main vegetable species that is widely cultivated and consumed in the world due to their high nutrient content and distinctive taste (Breksa et al. 2015; Li et al. 2018). In the last ten years, tomato is always rank first in vegetable production, and the latest data in 2016 shows tomato production of $177,042,359$ tons or about $16 \%$ of all vegetable production in the world (FAOSTAT 2018). Tomatoes are generally cultivated in the highlands $(>600$ $\mathrm{m}$ above sea level) in order to produce optimum yield, however, from around 49.87 million ha of potential land for annual crop cultivation in Indonesia only $6.74 \%$ is found in the highlands (Puslitbangtanak 2001). To encourage an increase in national production, extensification is needed in the middle-low elevation area while maintaining quality and productivity.

Increased tomato production in Indonesia is constrained by the limited adaptive high yielding varieties in the lowlands. Some commercial varieties in Indonesia have decreased yields ranging from $4 \%-81 \%$ when planted in the lowlands (compared to those in the highlands), including decreases in fruit weight and quality (Sutjahjo et al. 2015; Romadhon et al. 2017). Tomatoes with large fruit sizes have a wider market and higher prices compared to the small ones (Liang et al. 2017; Rugchat 2017). The assembly of large fruit tomato varieties that continue to produce high in the lowlands is one of the ideas that can be done, so that large fruit-sized lines can still produce optimum in the lowlands.

In developing plant breeding programs, information about genetic models, heritability, and the magnitude of the action of genes that control a character are important to know. The gene action model is assessed as one of the three main information needed in genetic evaluation in addition to the number of genes controlling the character and genotype $\mathrm{x}$ environmental interaction (Souza et al. 2012; Said 2014). Heritability values reflect the potential for genetic progress that can be obtained on a character. The use of characters that have high heritability will help breeders to obtain desired genetic gain from existing resources (Ogunniyan and Olakojo 2014; Ohlson and Foolad 2015; Rukundo et al. 2017).

Epistasis gene action is one of the genetic variability components other than additive and dominant. In the action of the epistasis gene, the phenotype is determined by the interaction of alleles from different loci (Roy 2000). In the environmental stress conditions, epistasis genes can be more involved, specifically in initiating resistance mechanisms (Hansen 2013). Epistasis gene action plays an important role in plant adaptation to abiotic stresses such as Al stress (Sihaloho et al. 2105) and Fe (Nugraha et al. 
2016), as well as high-temperature stress caused by differences in altitude. In Indonesia, tomatoes are generally cultivated in the highlands with a daily temperature range of $16-30^{\circ} \mathrm{C}$ to achieve high production. The performance of tomatoes on the middle-low plain is thought to be highly influenced by the action of the epistasis gene due to hightemperature stress.

To estimate a genetic model and gene action that control a quantitative character, the analysis of the average generation using a joint scaling test is one of the commonly used methods. This analysis can provide information about the action of average genes (additive effects), dominance ranges, non-allelic interactions, and the genetic values of family and generation averages (Mather and Jinks 1982). The design of bi-parental crosses using the basic population $\mathrm{P} 1, \mathrm{P} 2, \mathrm{~F} 1, \mathrm{BCP} 1, \mathrm{BCP} 2$, and F2 has been widely used to study the inheritance of qualitative and quantitative characters in tomatoes, such as lycopene and ascorbic acid (Dubey et al. 2014), shelf life fruit (Rodri'guez et al. 2010), agronomic characters (Kanneh et al. 2017), and yield components (Shalaby 2013). In this study, generation means analysis was carried out from crossing large tomatosized (not adaptive to lowland) lines with a medium-sized tomato line that is adaptive in the lowlands. The study aims to obtain information on genetic control of yield and yield components, as a consideration in improving the effectiveness and efficiency of the selection activity.

\section{MATERIALS AND METHODS}

\section{Study area}

This study located at an altitude of $518 \mathrm{~m}$ above sea level (medium elevation) with minimum and maximum temperatures of 17.6 and $37.8^{\circ} \mathrm{C}$, as well as minimum and maximum air humidity of 37 and $99 \%$ respectively. The research was conducted in November 2017-November 2018 at the PT BISI International Tbk Farm in Citapen Village, Bogor, West Java.

\section{Plant materials}

The genetic materials consisted of six populations ( $\mathrm{P} 1$, P2, F1, BCP1, BCP2, and F2) from each set of crosses between semi-indeterminate lines (97D and 99D) with determinate line (Tora). Semi-indeterminate lines are large fruiting lines and high productivity in the highlands, while determinate line is an adaptive line in the lowlands (Shanmukhi et al. 2018). In a previous experiment conducted at an altitude of $1241 \mathrm{~m}$ above sea level (Hermanto et al. 2017), the parent lines used in this experiment had the character of fruit weight and weight per plant of $99.95 \mathrm{~g}$ and $2.29 \mathrm{~kg}$ (99D), respectively; $99.68 \mathrm{~g}$ and $2.12 \mathrm{~kg}$ (97D); $53.43 \mathrm{~g}$ and $1.70 \mathrm{~kg}$ (Tora). The complete population set of the cross I (C-I, 99D x Tora) and cross II (C-II, 97D x Tora) each consisted of $40 \mathrm{P} 1,40$ P2, 40 F1, 120 BCP1, 120 BCP2, and 270 F2.

\section{Field experiment}

The complete populations of P1, P2, F1, BCP1, BCP2, and F2 from each set of crosses were planted in a greenhouse in two rows per single bed (double row) with a distance within $0.6 \times 0.6 \mathrm{~m}^{2}$ and distance between beds 0.8 $\mathrm{m}$. The size of the bed is $12 \times 1 \mathrm{~m}^{2}$, so that in one bed consists of 40 plants. The composition of fertilizer used was 10 tons ha- manure, 1.4 tons $\mathrm{ha}^{-1} \mathrm{NPK}$ as basic fertilizer, $350 \mathrm{~kg} \mathrm{ha}^{-1} \mathrm{ZA}$. Dolomite lime at 2 tons ha-1 was given at 10 days before planting. Then, the beds were covered using black silver plastic mulch. Plant maintenance consisted of irrigation, fertilizer application, pest, and disease control. Supplementary fertilizer was given at 4, 6 and 8 weeks after planting in the form of NPK fertilizer solution (16:16:16) at a concentration of $10 \mathrm{~g} \mathrm{~L}^{-1}$ by pouring $250 \mathrm{ml}$ per plant on a hole as far as $8-10 \mathrm{~cm}$ from the base of the plant stem. Weed control was done manually. Harvest was carried out when the fruit is evenly red. Observations were made on characters of flowering time, harvest time, fruit length, fruit diameter, fruit weight, fruit weight per plant, and number of fruits per plant.

\section{Data analysis}

Components of additive, dominant, and environmental variability were calculated based on Mather (1949). The estimation of broad sense and narrow sense heritability referred to Warner (1952), with classification into three classes, namely high if $h^{2} \geq 0.6$, moderate if $0.3 \geq h^{2}>0.6$, and low if $h^{2}<0.3$ (Shokat et al. 2015). The degree of dominance was used to predict gene action in controlling a character. The degree of domination was estimated by a formula $[\mathrm{H} / \mathrm{D}]^{1 / 2}$, in which $\mathrm{H}$ is the dominant variance, and $\mathrm{D}$ is the additives variance.

The mean analysis was conducted as joint scaling test method by Mather and Jink (1982) with three genetic components, namely the mean value [m], the additive effects [d], and the influence of dominance [h]. If the gene action does not meet the additive-dominant model, then a test is carried out to determine the presence or absence of non-allelic gene interactions using epistatic models with six components with additive $\mathrm{x}$ additives [i], dominant $\mathrm{x}$ additives [j], and dominant $\mathrm{x}$ dominant [1] as additional components to the model, followed by test for the goodness of fit to determine the most suitable model (Singh and Chaudhary 1979). Computation was done using SAS software and MS Excel.

\section{RESULTS AND DISCUSSION}

\section{Temperature stress evaluation}

One of the main problems in introducing high-yielding tomato varieties adapted in highlands for the lowlands is the presence of high-temperature stress which causes negative effects on the growth, reproduction, yield components, and disease resistance (Solankey et al. 2015). The optimal temperature for tomatoes is $20-30^{\circ} \mathrm{C}$ during the day and around $20^{\circ} \mathrm{C}$ at night (Camejo et al. 2005). In Indonesia, the optimal temperature for tomatoes is in the highlands, so extensification of tomato cultivation in the lowlands requires adaptive varieties at higher temperatures. 
Table 1. Comparison of the mean values of fruit weight and fruit weight per plant of 99D, 97D, and Tora at different altitudes.

\begin{tabular}{lcccc}
\hline \multirow{2}{*}{ Genotipe } & \multicolumn{2}{c}{$\begin{array}{c}\text { Hermanto et al. } \\
(\mathbf{2 0 1 7}) *\end{array}$} & \multicolumn{2}{c}{ Present study** } \\
\cline { 2 - 5 } & FW & FWP & FW & FWP \\
\hline 99D & 99.95 & 2.29 & 85.28 & 1.81 \\
97D & 88.68 & 2.12 & 57.31 & 1.11 \\
Tora & 53.43 & 1.70 & $77.11^{\mathrm{m}}$ & $2.81^{\mathrm{m}}$ \\
\hline Note: $*=1241 \mathrm{~m}$ asl, $* *=518 \mathrm{~m}$ asl, ${ }^{\mathrm{m}}=$ average of Tora at C-I \\
and C-II, FW = fruit weight $(\mathrm{g}), \mathrm{FWP}=$ fruit weight per plant \\
(kg).
\end{tabular}

In the present study, the decrease in the performance of the parental line 97D was observed in the main characters of yield component, i.e., fruit weight and weight per plant, compared to those when planting in the highland (Table 1). The genotype 97D (P1) is a semi-indeterminate line, an adaptive line in highlands, which should have a higher yield component mean value than Tora (P2), but not in this study. The other parental line, 99D also experienced a reduced performance. In addition, Tora as a lowland adaptive parent has better performance in the current study than when planting at an altitude of $1241 \mathrm{~m}$ above sea level (Hermanto et al. 2017). This confirms that there is temperature stress on the middle-low elevation compared to the highlands, which can result in a decrease in yield components in tomatoes, especially non-determinate varieties that have high yield potential.

\section{Gene action}

Determination of the genetic model in quantitative character inheritance can be done through the dominant additive model conformity test with individual scale tests (scaling test) and joint scaling test. The assumptions that must be fulfilled in the analysis are homozygous parents, diploid inheritance patterns, no gene linkages, no maternal effects, no genotype interactions with the environment, and interactions between only two genes and two alleles (Allard 1960; Hill et al. 1998). In this study, all assumptions have been fulfilled.

\section{Flowering time}

Comparison of the inter-generational mean value for the flowering time character showed higher variability in the cross II than cross I (Table 2). The populations resulting from crosses produce offspring that have a longer flowering time than both parents, which shows an overdominant gene action. The same sign (negative) between components [h] and [1] in cross I indicates the type of action of complementary epistasis genes (Table 4), while in cross II indicate the type of duplicate epistasis as shown from the difference in signs (positive-negative) between components [h] and [1] it. The goodness of fit test results shows that cross I have an additive-dominant genetic model with the dominant $\mathrm{x}$ dominant interaction effect. For cross II, significant results in each model both in the scaling test and joint scaling test showed an interaction model that was digenic or even trigenic (Roy 2000).

\section{Harvest time}

F1 values of harvest time at both crosses showed a higher additive gene action in cross I compared to cross II (Table 2). The difference in the sign between the dominant component $[\mathrm{h}]$ and the dominant $\mathrm{x}$ dominant [1], indicates that harvest time is controlled by duplicate epistasis gene action in both crosses, but at cross I the interaction causes a decrease in the mean value, while in cross II increases the mean value (Table 4). The appropriate genetic model based on the test for the goodness of fit (Singh and Chaudhary 1979) for the cross I indicates an additive-dominant with additive $\mathrm{x}$ additive and additive $\mathrm{x}$ dominant, while cross II has an additive-dominant model with additive $\mathrm{x}$ additive and dominant $\mathrm{x}$ dominant epistasis.

Table 2. Mean value ( \pm standard deviation) for flowering time, harvest time, fruit length, and fruit diameter in the population from two different crosses of tomato.

\begin{tabular}{|c|c|c|c|c|}
\hline \multirow{2}{*}{ Population } & \multicolumn{4}{|c|}{ Mean } \\
\hline & FT & HT & FL & FD \\
\hline \multicolumn{5}{|c|}{ 99D x Tora (C-I) } \\
\hline $\mathrm{P} 1$ & $22.40 \pm 2.04$ & $73.03 \pm 4.15$ & $6.65 \pm 0.39$ & $4.51 \pm 0.39$ \\
\hline P2 & $22.45 \pm 2.13$ & $66.92 \pm 3.76$ & $5.35 \pm 0.37$ & $4.51 \pm 0.36$ \\
\hline $\mathrm{F} 1$ & $22.96 \pm 1.79$ & $69.74 \pm 4.31$ & $5.77 \pm 0.39$ & $4.53 \pm 0.37$ \\
\hline BCP1 & $23.46 \pm 3.16$ & $71.09 \pm 6.59$ & $6.18 \pm 0.52$ & $4.15 \pm 0.44$ \\
\hline ВСР2 & $23.97 \pm 3.45$ & $69.65 \pm 5.96$ & $5.74 \pm 0.48$ & $4.63 \pm 0.41$ \\
\hline F2 & $24.00 \pm 2.36$ & $72.31 \pm 4.65$ & $5.79 \pm 0.63$ & $4.44 \pm 0.54$ \\
\hline \multicolumn{5}{|c|}{ 97D x Tora (C-II) } \\
\hline $\mathrm{P} 1$ & $23.22 \pm 1.54$ & $72.42 \pm 2.64$ & $4.55 \pm 0.47$ & $4.37 \pm 0.59$ \\
\hline $\mathrm{P} 2$ & $22.48 \pm 1.64$ & $70.06 \pm 3.73$ & $5.60 \pm 0.40$ & $4.80 \pm 0.38$ \\
\hline $\mathrm{F} 1$ & $19.68 \pm 1.47$ & $65.20 \pm 2.74$ & $5.34 \pm 0.46$ & $5.16 \pm 0.51$ \\
\hline BCP1 & $21.93 \pm 2.19$ & $70.29 \pm 5.23$ & $5.28 \pm 0.54$ & $5.38 \pm 0.72$ \\
\hline BCP2 & $24.60 \pm 3.34$ & $69.13 \pm 4.49$ & $5.07 \pm 0.53$ & $4.73 \pm 0.70$ \\
\hline $\mathrm{F} 2$ & $19.78 \pm 1.66$ & $67.77 \pm 4.80$ & $5.33 \pm 0.59$ & $5.06 \pm 0.79$ \\
\hline
\end{tabular}

Note: C-I = cross I, C-II = cross II, FT = flowering time (dap), HT = harvest time (dap), FL = fruit length $(\mathrm{cm}), \mathrm{FD}=$ fruit diameter $(\mathrm{cm})$ 
Table 3. Mean value ( \pm standard deviation) for fruit weight, fruit weight per plant, and number of fruits in the population from two different crosses of tomato

\begin{tabular}{lccc}
\hline \multirow{2}{*}{ Population } & \multicolumn{2}{c}{ Mean } & NF \\
\cline { 2 - 4 } 99D x Tora (C-I) & FW & FWP & $55.94 \pm 17.67$ \\
P1 & & & $86.84 \pm 18.17$ \\
P2 & $85.28 \pm 15.32$ & $3045.71 \pm 895.15$ & $85.39 \pm 18.05$ \\
F1 & $74.82 \pm 13.36$ & $2856.86 \pm 880.64$ & $56.15 \pm 22.44$ \\
BCP1 & $76.41 \pm 13.13$ & $1643.53 \pm 821.63$ & $72.70 \pm 25.17$ \\
BCP2 & $70.56 \pm 16.07$ & $2725.57 \pm 1198.38$ & $59.78 \pm 23.96$ \\
F2 & $81.07 \pm 16.90$ & $2056.28 \pm 1142.70$ & \\
97D x Tora (C-II) & $76.37 \pm 20.66$ & $1110.00 \pm 690.00$ & $25.11 \pm 17.29$ \\
P1 & & $2579.35 \pm 715.69$ & $75.71 \pm 17.25$ \\
P2 & $57.31 \pm 18.58$ & $2061.35 \pm 984.84$ & $50.08 \pm 17.45$ \\
F1 & $79.40 \pm 13.43$ & $2108.33 \pm 1435.59$ & $49.45 \pm 23.78$ \\
BCP1 & $88.17 \pm 19.57$ & $1447.37 \pm 745.20$ & $41.76 \pm 18.58$ \\
BCP2 & $98.62 \pm 32.53$ & $1725.31 \pm 1059.31$ & $40.08 \pm 20.80$ \\
F2 & $74.76 \pm 23.93$ & $92.76 \pm 32.63$ & \\
\hline
\end{tabular}

Note: $\mathrm{C}-\mathrm{I}=$ cross I, C-II = cross II, FW = fruit weight $(\mathrm{g}), \mathrm{FWP}=$ fruit weight per plant $(\mathrm{g}), \mathrm{NF}=$ number of fruits

Table 4. Estimates of gene action ( $\pm \mathrm{SE}$ of mean) for various yield traits in two different crosses of tomato using six components.

\begin{tabular}{|c|c|c|c|c|c|c|c|}
\hline \multirow{2}{*}{ Character } & \multicolumn{6}{|c|}{ Gene action } & \multirow{2}{*}{$\begin{array}{c}\text { Appropriate } \\
\text { model }\end{array}$} \\
\hline & $\mathbf{m}$ & d & h & $\mathbf{i}$ & $\mathbf{j}$ & 1 & \\
\hline \multicolumn{8}{|c|}{ Flowering time } \\
\hline C-I & $24.00 \pm 0.17 * *$ & $-0.51 \pm 0.43$ & $-0.59 \pm 1.16$ & $-1.13 \pm 1.09$ & $-0.49 \pm 0.49$ & $-2.96 \pm 2.02$ & \multirow{2}{*}{$\mathrm{m}[\mathrm{d}][\mathrm{h}][\mathrm{l}]$} \\
\hline C-II & $19.74 \pm 0.11^{* *}$ & $-2.50 \pm 0.41 * *$ & $10.59 \pm 0.98 * *$ & $13.75 \pm 0.93^{* *}$ & $-2.87 \pm 0.46 * *$ & $-21.39 \pm 1.81 * *$ & \\
\hline \multicolumn{8}{|c|}{ Harvest time } \\
\hline C-I & $72.31 \pm 0.35^{* *}$ & $1.44 \pm 0.84 *$ & $-8.02 \pm 2.35 * *$ & $-7.78 \pm 2.18 * *$ & $-1.61 \pm 0.97 *$ & $5.73 \pm 4.03$ & $\mathrm{~m}[\mathrm{~d}][\mathrm{h}][\mathrm{i}][\mathrm{j}]$ \\
\hline C-II & $67.78 \pm 0.31 * *$ & $1.16 \pm 0.78$ & $3.65 \pm 2.10 *$ & $9.68 \pm 1.99 * *$ & $-0.02 \pm 0.93$ & $-17.59 \pm 3.62 * *$ & $\mathrm{~m}[\mathrm{~d}][\mathrm{h}][\mathrm{i}][\mathrm{l}]$ \\
\hline \multicolumn{8}{|l|}{ Fruit length } \\
\hline $\mathrm{C}-\mathrm{I}$ & $5.79 \pm 0.05^{* *}$ & $0.45 \pm 0.07 * *$ & $0.47 \pm 0.24 *$ & $0.69 \pm 0.23 * *$ & $-0.20 \pm 0.08 * *$ & $-0.99 \pm 0.36 * *$ & \\
\hline C-II & $5.33 \pm 0.04 * *$ & $0.21 \pm 0.07 * *$ & $-0.35 \pm 0.24$ & $-0.62 \pm 0.21 * *$ & $0.73 \pm 0.10 * *$ & $0.75 \pm 0.39 *$ & $\mathrm{~m}[\mathrm{~d}][\mathrm{h}][\mathrm{i}][\mathrm{j}]$ \\
\hline \multicolumn{8}{|c|}{ Fruit diameter } \\
\hline C-I & $4.44 \pm 0.04 * *$ & $-0.48 \pm 0.06^{* *}$ & $-0.18 \pm 0.21$ & $-0.20 \pm 0.20$ & $-0.48 \pm 0.07 * *$ & $0.73 \pm 0.32 *$ & $m[d][h][j][1]$ \\
\hline C-II & $5.06 \pm 0.05 * *$ & $0.65 \pm 0.10^{* *}$ & $0.53 \pm 0.31 *$ & $-0.05 \pm 0.28$ & $0.86 \pm 0.12 * *$ & $-0.66 \pm 0.49$ & $\mathrm{~m}[\mathrm{~d}][\mathrm{h}][\mathrm{j}][\mathrm{l}]$ \\
\hline \multicolumn{8}{|l|}{ Fruit weight } \\
\hline C-I & $76.37 \pm 1.55^{* *}$ & $-10.52 \pm 2.21 * *$ & $-5.86 \pm 8.12$ & $-2.23 \pm 7.61$ & $-15.75 \pm 2.79 * *$ & $11.89 \pm 12.18$ & $\mathrm{~m}[\mathrm{~d}][\mathrm{h}][\mathrm{j}][\mathrm{l}]$ \\
\hline C-II & $92.77 \pm 2.13 * *$ & $23.86 \pm 3.88 * *$ & $-4.49 \pm 12.24$ & $-24.31 \pm 11.52 *$ & $34.90 \pm 4.69 * *$ & $-9.39 \pm 19.55$ & $\mathrm{~m}[\mathrm{~d}][\mathrm{h}][\mathrm{i}][\mathrm{j}]$ \\
\hline \multicolumn{8}{|c|}{ Fruit weight per plant } \\
\hline C-I & $2056.29 \pm 85.41 * *$ & $-1082.04 \pm 136.47 * *$ & $939.11 \pm 478.59^{*}$ & $513.05 \pm 437.28$ & $-467.06 \pm 169.56^{* *}$ & $1324.06 \pm 752.37 *$ & $m[d][h][j][1]$ \\
\hline C-II & $1725.31 \pm 68.52 * *$ & $660.97 \pm 155.05^{* *}$ & $343.57 \pm 481.09$ & $210.16 \pm 413.87$ & $1395.64 \pm 226.51^{* *}$ & $323.95 \pm 836.93$ & $\mathrm{~m}[\mathrm{~d}][\mathrm{h}][\mathrm{i}][\mathrm{j}]$ \\
\hline \multicolumn{8}{|c|}{ Number of fruits } \\
\hline C-I & $59.78 \pm 1.79 * *$ & $-16.55 \pm 3.18 * *$ & $32.61 \pm 10.39 * *$ & $18.61 \pm 9.56 *$ & $-1.10 \pm 3.88$ & $37.24 \pm 16.69 *$ & $\mathrm{~m}[\mathrm{~d}][\mathrm{h}][\mathrm{i}][\mathrm{l}]$ \\
\hline C-II & $40.08 \pm 1.35 * *$ & $7.70 \pm 2.92 * *$ & $21.78 \pm 9.02 * *$ & $22.12 \pm 7.95 * *$ & $32.99 \pm 4.34 * *$ & $-3.55 \pm 15.45$ & $\mathrm{~m}[\mathrm{~d}][\mathrm{h}][\mathrm{i}][\mathrm{j}]$ \\
\hline
\end{tabular}

\section{Fruit length}

The mean value of the fruit length of the F1 population in each cross (I \& II) was between the values of the two parents (Table 2), indicating an additive gene action in this character. The difference in sign between the component [h] and [1] shows the existence of duplicate epistasis with a positive effect in cross I and a negative effect in cross II (Table 4). Similar results were also reported by Somraj et al. (2018) on fruit length character. The genetic model that is suitable for the character of fruit length in cross II is additive-dominant with additive $\mathrm{x}$ additives and dominant $\mathrm{x}$ additives, while in cross I the genetic model cannot be detected using a five-component combination model.

\section{Fruit diameter}

The fruit diameter character has the same genetic model in both crosses, namely additive-dominant models with additive $\mathrm{x}$ dominant and dominant $\mathrm{x}$ interactions. The dominant effect $[\mathrm{h}]$ is greater than the additive $[\mathrm{d}]$ in cross I and vice versa in cross II (Table 4). Fruit diameters at both crosses also have duplicate epistasis gene action, which is known from the difference in sign between the dominant 
component $[\mathrm{h}]$ and the dominant $\mathrm{x}$ dominant [1] interaction. The type of duplicate epistasis gene action is relatively difficult for breeders selection due to the magnitude of dominant effects and unpredictable interactions (Zdravković et al. 2011; Mistry et al. 2016).

\section{Fruit weight}

Comparison of the mean values of fruit weight between populations showed a greater additive gene action in cross II than cross I (Table 3). Genetically, additive gene action can be used in the long term by concentrating the desired gene in a homozygous genotype state. The segregating population from cross II have good potential in the development of pure strain varieties.

The character of fruit weight in cross I has duplicate epistasis gene action, while cross II has complementary epistasis gene action (Table 4). Duplicate epistasis in fruit weight was also reported by Devi et al. (2005), Zdravković et al. (2011), and Thainukul et al. (2017), while complementary epistasis was reported by Singh et al. (2015). The appropriate genetic model for fruit weight in cross $\mathrm{I}$ is an additive-dominant model with additive $\mathrm{x}$ dominance and dominant $\mathrm{x}$ dominant, while the cross II model is dominant with additive $\mathrm{x}$ additive and additive $\mathrm{x}$ dominant interaction.

\section{Fruit weight per plant}

Comparison of the mean values of weight per plant between populations $\mathrm{P} 1, \mathrm{P} 2$, and F1 indicates an additive influence on this character. Fruit weight per plant is a character that is very much considered in tomato cultivation. Fruit weight per plant is known to have a high and positive correlation with fruit weight (Ritonga et al. 2018), so the improvement of one character will affect the other characters.

Complementary epistasis gene action was obtained on fruit weights per plant in both crosses (Table 4). This is similar to that reported by Devi et al. (2005) and Somraj et al. (2018). The appropriate genetic model for fruit weight in cross $\mathrm{I}$ is an additive-dominant model with additive $\mathrm{X}$ dominance and dominant $\mathrm{x}$ dominant, while the cross II model is dominant with additive $\mathrm{x}$ additive and additive $\mathrm{x}$ dominant interaction.

\section{Number of fruits}

Estimation of gene action using three components shows the existence of non-allelic interactions on the character of the number of fruits, judging from the significance of the components used. Estimation with six components shows the existence of complementary epistasis gene action in the number of fruits per plant in the cross I and epistasis duplicates at cross II (Table 4). Complementary epistasis on the number of fruit characters reported by Devi et al. (2005) and Zdravković et al. (2011), whereas epistasis was duplicated by Singh et al. (2015) and Somraj et al. (2018). The test results of the goodness of fit indicate that the additive-dominant genetic model with additive $\mathrm{x}$ additive and dominant $\mathrm{x}$ interaction is appropriate for the cross $\mathrm{I}$, and additive-dominant with additive $\mathrm{x}$ additive and additive $\mathrm{x}$ dominant interactions suitable for the cross II in this character.

Table 5. Genetic variances and heritability of various traits studied in two different crosses of tomato using six components.

\begin{tabular}{|c|c|c|c|c|c|c|}
\hline \multirow{2}{*}{ Character } & \multicolumn{3}{|c|}{ Variances } & \multirow{2}{*}{$\sqrt{\mathrm{H} / \mathrm{D}}$} & \multirow{2}{*}{$h^{2}{ }_{b}(\%)$} & \multirow{2}{*}{$h^{2}{ }_{n}(\%)$} \\
\hline & D & $\mathbf{H}$ & $\mathbf{E}$ & & & \\
\hline \multicolumn{7}{|c|}{ Flowering time } \\
\hline C-I & -32.62 & 71.58 & 3.96 & 1.48 & 28.58 & -193.87 \\
\hline C-II & -26.48 & 54.28 & 2.41 & 1.43 & 12.08 & -383.21 \\
\hline \multicolumn{7}{|l|}{ Harvest time } \\
\hline C-I & -114.66 & 249.21 & 16.65 & 1.47 & -23.00 & -165.17 \\
\hline C-II & -114.66 & 270.42 & 11.34 & 1.54 & 47.53 & -165.17 \\
\hline \multicolumn{7}{|l|}{ Fruit length } \\
\hline C-I & -0.22 & 1.45 & 0.15 & 2.57 & 63.16 & 72.50 \\
\hline C-II & -0.44 & 1.50 & 0.20 & 1.84 & 44.03 & 37.14 \\
\hline \multicolumn{7}{|c|}{ Fruit diameter } \\
\hline C-I & -0.16 & 0.92 & 0.14 & 2.39 & 51.45 & 72.41 \\
\hline C-II & -0.74 & 2.99 & 0.25 & 2.01 & 59.79 & 41.27 \\
\hline \multicolumn{7}{|l|}{ Fruit weight } \\
\hline C-I & -233.90 & 1394.85 & 195.19 & 2.44 & 54.28 & 72.61 \\
\hline C-II & -1132.80 & 5312.81 & 302.94 & 2.17 & 71.55 & 46.80 \\
\hline \multicolumn{7}{|c|}{ Fruit weight per plant } \\
\hline C-I & -1610867.38 & 5586592.54 & 714540.60 & 1.63 & 45.28 & 38.32 \\
\hline C-II & -2988194.86 & 7853917.79 & 652748.91 & 1.62 & 41.83 & -33.15 \\
\hline \multicolumn{7}{|c|}{ Number of fruits } \\
\hline C-I & -1125.82 & 3257.39 & 322.70 & 1.70 & 43.79 & 1.96 \\
\hline C-II & -956.72 & 2442.19 & 300.37 & 1.60 & 30.56 & -10.59 \\
\hline
\end{tabular}

Note: $\mathrm{C}-\mathrm{I}=99 \mathrm{D} \times$ Tora, $\mathrm{C}-\mathrm{II}=97 \mathrm{D} \times$ Tora, $\mathrm{D}=$ additive, $\mathrm{H}=$ dominant, $\mathrm{E}=$ Environment, $\sqrt{\mathrm{H} / \mathrm{D}}=$ degree of dominance, $\mathrm{h}^{2} \mathrm{~b}=\mathrm{broad}$ sense heritability, $h^{2}{ }_{n}=$ narrow sense heritability 


\section{Components of variance and heritability}

The estimation of additive (D), dominant $(\mathrm{H})$, and environment (E) components based on Mather (1949) showed that the dominant variance values were greater than the various additives in all characters. This shows that the influence of dominant gene action is greater than additive gene action. The dominance level also shows a high value (> 1.00) on all characters, which indicates that the controlling genes have overdominant gene action. The high value of the dominance level also causes a low value of narrow sense heritability. This is due to the low role of additive gene action in the characters.

Heritability is defined as the proportion of the genetic variety of existing phenotypic diversity. There are differences in the proportion of genetic factors that control each trait in living things. This also causes variability in each generation, so an estimation of heritability is needed to predict the influence of genetic factors on the phenotype of a trait. Narrow sense heritability generally gets more attention from breeders because the additive influence of each allele can be inherited by the progenies, and its relationship is close to breeding values, so it relatively facilitates the selection process and increases the effectiveness of breeding programs (Syukur and Rosidah 2014; Duangjit et al. 2016; Mistry et al. 2016).

The estimation of narrow sense heritability shows a negative value on the character of the early flowering time and the beginning of harvest at both crosses, as well as the character of weights per plant and number of fruits at cross II (Table 5). Negative values indicate that the diversity of the characters is not inherited or $h_{n}^{2}=0$. This can be caused by the high influence of the environment and the action of epistasis on the genes controlling the related properties. The value of low heritability is found in the character of the number of fruit cross I (1.96), which means that direct selection of these characters will be less effective.

Moderate heritability was estimated in fruit length (37.14), fruit diameter (41.27), and fruit weight (46.80) of cross II, and weight per plant (38.32) of cross I. High heritability was estimated in fruit length (72.50), fruit diameter (72.41), and fruit weight (72.61) of the cross I, this is in line with that reported by Singh et al. (2015) and Rai et al. (2016). High heritability values indicate that the character has a high potential for genetic progress, and selection can be done in the early generation, whereas in characters with low heritability, selection should start at generation F3-F4 when genes begin to be fixed to avoid bias during selection. However, the estimation of heritability is influenced by the type of genetic material, sample size, sampling method, experimentation, calculation method, and the effect of linkages (Said 2014), so that other aspect is still needed in determining breeding steps.

In conclusion, the action of the epistasis gene was found in all of the observed characters, with more duplicate epitasis than complementary epistasis. The high influence of non-allelic interactions causes high levels of nonadditive gene action, which reflected in the heritability values of the observed characters. Moderate to high heritability was found in the character of fruit length, fruit diameter, fruit weight, and fruit weight per plant, with higher values in cross I for each character. This shows that cross I have a higher potential for genetic progress than cross II. The action of overdominant genes on each character indicates that breeding activities will be appropriate if directed to produce hybrid varieties. If pure line variety is the objective, then bulk or SSD method is recommended for the selection, due to the high nonadditive effects and non-allelic interactions in each character.

\section{ACKNOWLEDGEMENTS}

The authors would like to thank Rudy Hermanto and PT BISI International Tbk. for genetic material, technical advice, funding, and permission to use the company's research facilities for this research.

\section{REFERENCES}

Allard RW. 1960. Principles for Plant Breeding. John Wiley \& Sons, New York.

Breksa AP, Robertson LD, Labate JA, King BA, King DE. 2015. Physicochemical and morphological analysis of ten tomato varieties identifies quality traits more readily manipulated through breeding and traditional selection methods. J Food Compos Anal 42: 16-25.

Camejo D, Rodri'guez P, Morales MA, Dell'Amico J, Torrecillas A, Alarcon JJ. 2005. High temperature effects on photosynthetic activity of two tomato cultivars with different heat susceptibility. J Plant Physiol 162: 281-289.

Devi ES, Singh NB, Devi AB, Singh NG, Laishram JM. 2005. Gene action for fruit yield and its components in tomato (Lycopersicon esculentum Mill.). Indian J Genet 65 (3): 221-222.

Duangjit J, Causse M, Sauvage C. 2016. Efficiency of genomic selection for tomato fruit quality. Mol Breed 36 (3): 1-16.

Dubey R, Ojha MD, Prabhakar MK, Singh PK, Saha B. 2014. The generation means analysis for quality and value-added traits in tomato (Lycopersicon esculentum MIll.). Ann Agric Bio Res 19 (1): 128-133.

FAOSTAT. 2018. World production tomatoes. www.fao.org/faostat/en/\#data.

Hansen TF. 2013. Why epistasis is important for selection and adaptation. Evolution 67 (12): 3501-3511.

Hermanto R, Syukur M, Widodo. 2017. Estimation of genetic variance and heritability for yield and yield component of tomato (Lycopersicum esculentum Mill.) across at two locations. J Hort Indon 8 (1): 31-38.

Hill J, Becker HC, Tigerstedt PMA. 1998. Quantitative and Ecological Aspects of Plant Breeding. Chapman \& Hall, London.

Solankey SS, Singh RK, Baranwal DK, Singh DK. 2015. Genetic expression of tomato for heat and drought stress tolerance: an overview. Int J Veg Sci 21: 496-515.

Kanneh SM, Quee DD, Ngegba PM, Musa PD. 2017. Evaluation of tomato (Solanum lycopersicum L.) genotypes for horticultural characteristics on the upland in Southern Sierra Leone. J Agric Sci 9 (6): 213-220.

Li F, Song X, Wu L, Chen H, Liang Y, Zhang Y. 2018. Heredities on fruit color and pigment content between green and purple fruits in tomato. J Sci Hort 235:391-396.

Liang S, Jie C, Kai X, Wencai Y. 2017. Origin of the domesticated horticultural species and molecular bases of fruit shape and size changes during the domestication, taking tomato as an example. Hort Plant J 3 (3): 125-132.

Mather K. 1949. Biometrical Genetics. Dover, New York.

Mather K, Jinks JL. 1982. Biometrical Genetics $3^{\text {rd }}$ ed. Chapman \& Hall, New York.

Mistry C, Kathiria KB, Sabolu S, Kumar S. 2016. Heritability and gene effects for yield-related quantitative traits in eggplant. Ann Agric Sci 61 (2): 237-246. 
Nugraha Y, Ardie SW, Suwarno, Ghulamahdi M, Aswidinnoor H. 2016. Implication of gene action and heritability under stress and contro conditions for selection iron toxicity tolerant in rice. Agrivita J Agric Sci 38 (3): 282-295.

Ogunniyan DJ, Olakojo SA. 2014. Genetic variation, heritability, genetic advance and agronomic character association of yellow elite inbred lines of maize (Zea mays L.). Niger J Genet 28: 24-28.

Ohlson EW, Foolad MR. 2015. Heritability of late blight resistance in tomato conferred by Solanum pimpinellifolium accession PI 224710. Plant Breed 134: 461-467.

Puslitbangtanak [Pusat Penelitian dan Pengembangan Tanah dan Agroklimat]. 2001. Atlas Arahan Tata Ruang Pertanian Indonesia, skala 1:1.000.000. Badan Penelitian dan Pengembangan Pertanian, Jakarta. [Indonesian]

Rai AK, Vikram A, Pandav A. 2016. Genetic variability studies in tomato (Solanum lycopersicum L.) for yield and quality traits. Int J Agric Environ Biotech 9 (5): 739-744.

Ritonga AR, Chozin MA, Syukur M, Maharijaya A, Sobir. 2018. Genetic variability, heritability, correlation, and path analysis in tomato (Solanum lycopersicum) under shading condition. Biodiversitas 19 (4): 1527-1531. [Indonesian]

Romadhon MR, Sutjahjo SH, Wirnas D. 2017. Interaction genetic x environment putatif mutant lines tomato M5 on two agro ecosystems. Int J Agron Agric Res 10 (5): 102-112.

Roy D. 2000. Plant Breeding: Analysis and Exploitation of Variation. Narosa, New Delhi.

Rugchat J. 2017. From highland tomatoes to lowland markets: highland agriculture restructuring and power in Thailand tomatoes commodity network. $13^{\text {th }}$ International Conference on Thai Studies, Chiang Mai, Thailand, 15-18 July 2017.

Rodri'guez GR, Pratta GR, Liberatti DR, Zorzoli R, Picardi LA. 2010. Inheritance of shelf life and other quality traits of tomato fruit estimated from F1's, F2's and backcross generations derived from standard cultivar, nor homozygote and wild cherry tomato. Euphytica 176: 137-147.

Rukundo P, Shimelis H, Laing M, Gahakwa D. 2017. Combining ability, maternal effects, and heritability of drought tolerance, yield and yield components in sweet potato. Front Plant Sci 7 (1981): 1-14.

Said AA. 2014. Generation mean analysis in wheat (Triticum aestivum L.) under drought stress conditions. Ann Agric Sci 59 (2): 177-184.
Shalaby TA. 2013. Mode of gene action, heterosis and inbreeding depression for yield and its components in tomato (Solanum lycopersicum L.). J Sci Hort 164: 540-543.

Shanmukhi CH, Reddy MLN, Rao AVDD, Babu PA. 2018. Flowering and yield in processing tomato varieties as influenced by planting density and fertigation. J Pharmacognosy Phytochem 7 (2): 34813485 .

Shokat S, Azhar FM, Nabi G, Iqbal Q. 2015. Estimation of heritability and genetic advance for some characters related to earliness in tomato (Solanum lycopersicum L.). J Agric Res 53 (3): 351-355.

Sihaloho AN, Trikoesoemaningtyas, Sopandie D, Wirnas D. 2105. Identification of epistatic genes action controlling soybean tolerance to aluminum toxicity. J Agron Indon 43 (1): 3-35. [Indonesian]

Singh N, Ram CN, Deo C, Yadav GC, Singh DP. 2015. Genetic variability, heritability and genetic advance in tomato (Solanum lycopersicum L.). Plant Arch 15 (2): 705-709.

Singh RK, Chaudhary BD. 1979. Biometrical Methods in Quantitative Genetic Analysis. Kalyani, New Delhi.

Singh RK, Rai N, Kumar P, Singh AK. 2015. Inheritance study in tomato (Solanum lycopersicum) for Tomato leaf curl virus (ToLCV) resistance. Indian J Agric Sci 85 (7): 896-901.

Somraj B, Reddy RVSK, Reddy KR, Saidaiah P, Reddy MT. 2018. Generation means analysis of yield components and yield in tomato (Solanum lycopersicum L.) under high-temperature conditions. J Pharmacognosy Phytochem 7 (6): 1704-1708.

Souza LM, Paterniani MEA, Melo PCT, Melo AMT. 2012. Diallel cross among fresh market tomato inbreeding lines. Hort Bras 30: 246-251.

Sutjahjo SH, Herison C, Sulastrini, Marwiyah S. 2015. The estimation of genetic variability of growth and yield traits on 30 local tomato genotypes J Hort 25 (4): 304-310.

Syukur M, Rosidah S. 2014. Estimation of genetic parameter for quantitative characters of pepper (Capsicum annиит L.). J Trop Crop $1(1): 4-8$.

Thainukul N, Sakdarueakrot S, Yan L. 2017. The evaluation of genetic inheritance, heritability and correlations coefficient of mutant tomato. Sch J Agric Vet Sci 4 (5): 209-213.

Warner JN. 1952. A method for estimating heritability. Agron J 44: 427 430.

Zdravković J, Pavlović N, Girek Z, Brdar-Jokanović M, Savić D, Zdravković M, Cvikić D. 2011. Generation mean analysis of yield components and yield in tomato (Lycopersicon esculentum Mill.). Pak J Bot 43 (3): 1575-1580. 